Discussion

Papers
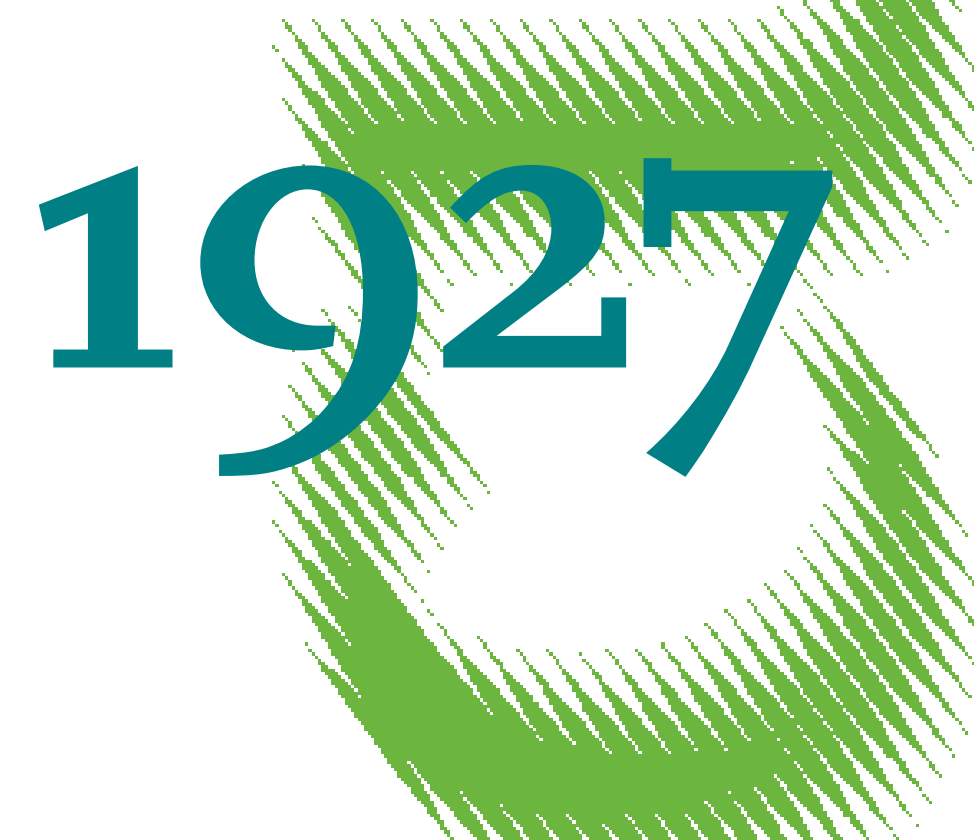

aillil

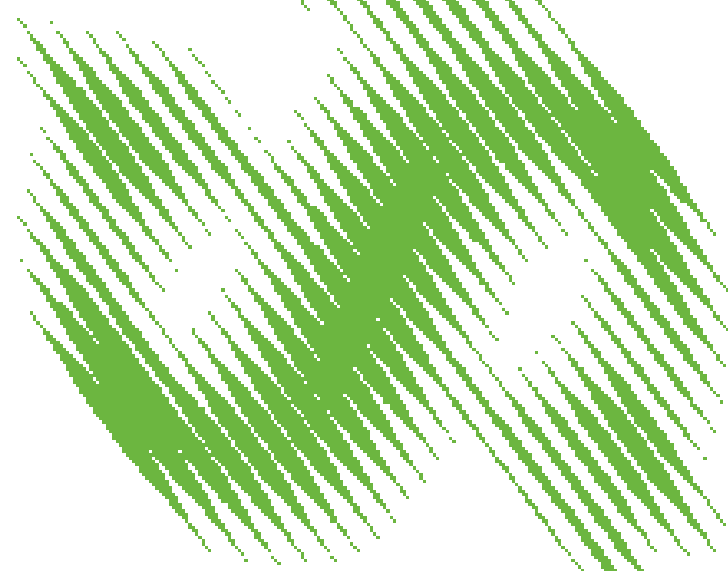

Rent Price Control - Yet Another Great Equalizer of Economic Inequalities?

Evidence from a Century of Historical Data 
Opinions expressed in this paper are those of the author(s) and do not necessarily reflect views of the institute.

IMPRESSUM

(C) DIW Berlin, 2021

DIW Berlin

German Institute for Economic Research

Mohrenstr. 58

10117 Berlin

Tel. +49 (30) $89789-0$

Fax +49 (30) $89789-200$

http://www.diw.de

ISSN electronic edition 1619-4535

Papers can be downloaded free of charge from the DIW Berlin website:

http://www.diw.de/discussionpapers

Discussion Papers of DIW Berlin are indexed in RePEc and SSRN:

http://ideas.repec.org/s/diw/diwwpp.html

http://www.ssrn.com/link/DIW-Berlin-German-Inst-Econ-Res.html 


\title{
Rent Price Control - Yet Another Great Equalizer of Economic Inequalities? Evidence from a Century of Historical Data
}

\author{
Konstantin A. Kholodilin \\ kkholodilin@diw.de \\ German Institute for Economic Research \\ (DIW Berlin) \\ and \\ National Research University - Higher School \\ of Economics in St. Petersburg \\ Sebastian Kohl ${ }^{1}$ \\ kohl@mpifg.de \\ Max-Planck-Institute \\ for the Study of Societies
}

\begin{abstract}
The long-run U-shaped patterns of economic inequality are standardly explained by basic economic trends (Piketty's r>g), taxation policies, or "great levelers," like catastrophes. This paper argues that housing policy, in particular rent control, is a neglected explanatory factor in understanding overall inequality. We hypothesize that rent control could decrease overall housing wealth, lower incomes of generally richer landlords, and increase disposable incomes of generally poorer tenants. Using original long-run data for up to 16 countries (1900-2016), we show that rent controls lowered wealth-to-income ratios, top income shares, Ginicoefficients, rent increases, and rental expenditure. A counterfactual analysis using microdata from the Luxembourg Income Study shows that rent controls could reduce rental expenditure of mostly lower-income tenants and rental incomes of mostly higher-income landlords. Overall, rent controls must be strict in order to have tangible effects and, historically, only strict rent controls have significantly reduced inequalities. The paper argues that housing policies should generally receive more attention in understanding economic inequalities.
\end{abstract}

Keywords: economic inequality, stratification, rent control

JEL codes: D31; E64; R38.

\footnotetext{
${ }^{1}$ Corresponding author.
} 


\section{Introduction}

With the publication of Thomas Piketty's "Capital in the $21^{\text {st }}$ Century," the U-shaped curve of inequality became one of the most stylized facts of our times (Piketty \& Zucman, 2013). The wealth-to-income ratio and income shares of the top- $1 \%$ or the top- $10 \%$ have fallen from the heights of the Belle Époque since World War I, reached a trough in the Trente Glorieuses of post-World War II, only to rise again since the 1970s, particularly in Anglophone countries. After 1990, post-socialist countries joined this general trend (Novokmet, Piketty, \& Zucman, 2018). With a few exceptions, as discussed below, these stylized facts, supported by the best available data, are largely uncontested. But what explains them?

Piketty's most recent book (2020) adds many more explanatory elements to this descriptive picture. Pushed by the moments of solidarity during the World Wars, governments enacted progressive income and wealth taxation, using it to finance welfare states and the extension of education. With the "ownership ideology" gaining the upper hand again in the 1970s, however, the progressivity of these taxes was cut back (Scheve \& Stasavage, 2016) and the democratization of tertiary education came to a halt (Piketty, 2020). In countries like the US, where the cut-back was particularly pronounced, the levels of inequality rose strongly, reaching the Golden-Age levels of more than a century ago. Others also highlight the "great levelling" effects that go along with wars (Scheidel, 2018). A rich literature on financialization (Godechot, 2020) shows how wages of the bottom 50\% could stagnate, while capital income of the top increased persistently.

This paper introduces a new, slightly hidden, explanatory factor into the debate, linking inequality to recent housing debates, namely rent control, mentioned by Piketty only en passant (2020, p. 436). This "minimum wage" of the housing market limits the incomes and housing values of generally richer landlords, while simultaneously increasing the disposable incomes of generally poorer tenant households. The very regressive incidence of rental expenditure and incomes make rent controls very progressive policy measures. Prima facie, the history of rent regulation fits the stylized inequality facts very well (cf. Figure 1 below): first introduced during the high-inequality war periods and prolonged in the aftermath of the wars, they were part of the solidarity package of high taxes on income and wealth that brought down inequality throughout the Trente Glorieuses (Voldman, 2013). They were lifted and deregulated at about the time when inequality started to rise again since the $1970 \mathrm{~s}$, but persisted as softer controls in more equal societies, while they were quickly abolished in high-inequality Anglophone countries. They had their all-time highs in the most equal socialist countries. The U-shaped curve of inequality over time is mirrored by an inverted $U$ of rent regulation.

To determine if this prima-facie evidence holds up, the paper conducts two broad empirical analyses: First, using a unique macro-panel of up to 16 countries in a time series between 1900 and 2016, based on an original combination of new long-run data, it finds that rent control is negatively associated with rent increases, rental expenditure, the top- $10 \%$ income share, Gini coefficient, and Piketty's wealth-to-income ratio, conditioned on a range of standard control 
variables including Piketty's $r>g$ for which we provide the first confirmatory long-run evidence. Second, for several waves of international micro surveys from the Luxembourg Income Study since the 1980s, we find that a counterfactual introduction of strict rent controls would lower inequality both from the perspective of landlords' rental income and from the perspective of households' disposable income. Thus, the post-housing-expenditure Gini decreases thanks to stricter rent controls: a 30\% rent reduction lowers the Gini by more than $1 \%$. This relatively strict measure has a tangible effect when compared, for instance, with the median $7 \%$ by which total welfare state measures have decreased the income Gini globally since 1950. At least from a short-term perspective, (strict) rent controls could, thusly, contribute to decreases of inequality, even if a longer-term perspective would have to take into account well-known side effects of strict rent controls, such as decreased tenant mobility, supply shortages, and quality problems (Oust, 2018).

The paper makes a larger case for including housing more systematically in the sociological study of inequality and stratification (pace Dewilde \& Lancee, 2013; Lux, Sunega, \& Katrňák, 2011). Housing has become the largest item in households' wealth portfolio and monthly expenses. Moreover, the unprecedented house price increases since 1990 are contributing to the increasing unaffordability of superstar cities, decoupling them economically and politically from stagnating hinterlands in many countries (Adler \& Ansell, 2019; Le Galès \& Pierson, 2019). With its links to family formation, neighborhood segregation, educational access, and political participation, housing inequalities are, moreover, prone to spill over into other social domains.

The paper is organized as follows: In the next section, we introduce the general inequality literature with some of its main explanations and then zoom in on the smaller housing and inequality literature to generate three guiding hypotheses. We then present our twofold empirical strategy along with the macro- and micro-data used. In the results section, we describe overall patterns in the data, run macro panel regressions, and conduct a counterfactual analysis on the micro data. After robustness tests, we discuss potential implications and limitations of our findings for further research.

\section{Literature: inequality and housing - the three channels}

We generally draw on two existing strands in the literature. The first is the broad literature on the fall and rise of inequality during the 20th century. We use this literature to inform our own analysis with the necessary control variables. The second more disparate and recent literature examines the role of housing for trends in inequality. From this literature, we derive three hypotheses that guide our empirical analysis.

The starting point for the more recent inequality literature is the observation of a growing trend in economic inequality, which occurred in many countries in the Global North, but also beyond, following a longer decline in the earlier 20th century (Piketty, 2014). Rising within-country inequality is matched by falling inequality between countries (Milanovic, 2011). Economic 
inequality is usually viewed through inequality of wealth and inequality of incomes, i.e., labor and capital income, with the fall and rise observable for both. The study of wealth inequality, due to data limitations, is much less developed than the study of income inequality and there is limited cross-country correlation between income and wealth inequality (Pfeffer \& Waitkus, 2020).

Piketty's own explanatory account contains many different elements, but key is the relationship between economic growth and interest rates. When economic and, hence, wage growth exceeds returns on capital, inequality should decrease. Surprisingly, this variable operationalized as difference between GDP growth and bond returns is either not significant or even has the wrong sign in (shorter) time series studies (Acemoglu \& Robinson, 2015; Góes, 2016). We complement these studies below with a much longer time series test.

Beyond Piketty's own explanatory account, there is a general consensus that extraordinary events, like catastrophes, revolutions, and wars, are the "great levelers" of wealth and income in history (Scheidel, 2018). Concerning the most recent historical time period, meaning since just before World War I, there is disagreement regarding which factors contributed to the levelling. Some highlight the redistributive effects of high income and wealth taxation (Scheve \& Stasavage, 2016), others point to the spillover of war-welfare into the growth of redistributive welfare states (Obinger, Petersen, \& Starke, 2018) or the surge in collective postwar investments (Haffert, 2019). With war solidarity fading, political measures ran out, thus allowing for a new rise in inequality. Rent controls themselves are a hitherto neglected part of these measures initiated during war times.

Less war-related, three other explanatory factors reflect power struggles between capital and labor, namely unionization, globalization, and financialization. Union membership has continuously fallen since WWII (Visser, 2006), accompanied by a decline of traditional leftwing parties and their turn to New Labour. This reduced wages in favor of profit sharing, while the deregulation of financial markets since the 1970s has continuously increased the income and profit sharing of the financial industry (Godechot, 2020). The simultaneous acceleration of international trade, in turn, exposed countries to higher competitive pressures and created divides between winners and losers within countries (Klein \& Pettis, 2020). Finally, more firmbased explanations of inequality focus on the technological changes in favor of high-skilled work, the monopsonization of labor markets, and increasing within-firm inequalities in multinational big corporations (Cobb \& Lin, 2017; Stansbury \& Summers, 2020)

Generally, housing is not a core theme in the inequality literature, even though it can affect income and wealth inequality through at least three channels: On the income side, housing can act as an income stream by generating rental income and capital gains. On the household expenditure side, it can also affect disposable income as it became the largest expenditure item during the 20th century, moving ahead of food (Reckendrees, 2007). With regard to wealth, housing is the largest wealth component in most households' wealth portfolios and house price changes can substantially alter its size (Christelis, Georgarakos, \& Haliassos, 2013; Kolb, Skopek, \& Blossfeld, 2013). 
Shortly after Piketty's English publication, Rognlie (2014, p. 3) pointed out that "nearly $100 \%$ of the long-term increase in the capital/income ratio, and more than $100 \%$ of the long-term increase in the net capital share of income" were actually due to housing wealth alone. Take away housing assets from national accounts and one of the central "capital-is-back" findings (Piketty \& Zucman, 2013) almost disappears. Not surprisingly, there is a near tautological relationship between house prices and wealth-to-income ratios (Fuller, Johnston, \& Regan, 2019). A similar result occurs when replacing the potentially inflated house-prices by the more fundamental rents as a measure of national housing wealth (Bonnet, Bono, Chapelle, \& Wasmer, 2014). How housing wealth is distributed is a crucial component of total wealth inequality: A study of Germany, covering 2002 to 2017, finds that the wealth inequality of primary residences contributes up to $16 \%$ to overall wealth inequality, while secondary real estate contributes up to $30 \%$ of wealth inequality to (Bartels \& Schroeder, 2020), because it is less equally distributed.

The relationship between rent regulation and housing wealth receives little attention, even though rent regulations are probably one of the most important factors determining the rate of return on housing investment. Research on strict rent controls in interwar France suggests that they were able to substantially reduce overall housing values (Bonneval \& Robert, 2013). Rent controls can act as a disciplining device for house prices. From this, we deduce a first hypothesis about the relationship of rent price controls and housing capital:

\section{Housing-capital hypothesis: Rent controls decrease the size of total housing wealth and, hence,} the overall wealth-to-income ratio.

Rent controls may not just affect housing values but also more directly the income flows from residential real estate. Households can own real estate directly or indirectly through investment funds. The European Central Bank Household Finance and Consumption Survey from 2013 and 2017 quantifies the former component: $8.8 \%$ of all Eurozone households receive rental income, which makes up $11.5 \%$ of their general income (ECB, 2013). While there are selfemployed, below-median-income, and even poor households for which rental income makes up a substantial income share, perhaps compensating for precarious welfare provision (Wind, Dewilde, \& Doling, 2020), generally rental-income households are small, old, homeowners themselves, high-income, high-education, and very high wealth owning (Ziegelmeyer, 2015). The socio-demographics and numbers are in fact a bit reminiscent of Paris rentiers of the Belle Époque (Daumard \& Codaccioni, 1973) and, perhaps not surprisingly, the term "rentier" is being revived (Christophers, 2020). In Germany, a study reveals that rental income, although making up only about $3 \%$ total pre- or post-government income in 2017 , is crucial for total inequality because it is very unevenly earned (Bartels \& Schroeder, 2020): up to 12,000 euro in 2017 for the average landlord compare to about 26,000 euro in disposable income of the average household. The standard economic-textbook assumption is that rent controls, as price caps, obviously limit the rental income flows and, hence, returns, even though the anticipation of controls could lower housing values simultaneously. Landlords might switch to alternative safe assets, as reported for institutional investors, upon the re-introduction of softer price controls in European countries in the 1970s (Lehnhardt-Ritter, 1984) or they might convert 
rental real estate into owner-occupied properties (Fetter, 2013; Kholodilin, Kohl, Prozorova, \& Licheron, 2018). To the extent that rental income is very unevenly distributed in societies, we would expect that:

Rental-income hypothesis: Rent controls decrease income flows from rental housing for landlords and, hence, reduce overall income inequality.

The flipside of this zero-sum game of rent regulation is that tenant households have more disposable income after housing costs. Inequality is usually measured by market or disposable income, i.e., before and after state redistribution. These concepts, however, ignore the potential inequalities caused by the consumption side of household budgets. These would be inexistent if households were to consume equal shares of their incomes on all goods such that price inflation and deflation would affect all households similarly. Yet, even in the 1860s, statisticians noted that there is an inverse relationship between household income and the budget share devoted to basic necessary (or inferior) goods, also known as Engel's law for food expenses and Schwabe's law for housing expenses (Schwabe, 1868). This can make the typical household basket and budget dependent on people's income. These income-specific inflation rates and their effects on inequality are the subject of contemporary research. One comprehensive study, for instance, looks at the household-income-specific inflation rates in the European Union (Gürer \& Weichenrieder, 2020): across 25 EU countries, the lowest income decile had a $11.2 \%$ higher inflation rate between 2001 and 2015 (or yearly 0.76 percentage points higher) than the top decile, which translates into an underestimation of the Gini of 0.04 points. A recent study of German housing expenditures finds that "the 50/10 ratio of net household income increases from 1.75 to 1.97 (by 22 percentage points, henceforth pp) between 1993 and 2013, while the same ratio net of housing expenditures increases from 1.97 to 2.59 (by 62 pp)" (Dustmann, Fitzenberger, \& Zimmermann, 2018, p. 1). In short, the "Schwabian" distribution of rent loads makes rent prices and their changes an important vector for inequality on the consumption side of household budgets. From this research, we deduce the third hypothesis:

Rental-expenditure hypothesis: Rent controls decrease rental expenditure and, hence, posthousing expenditure inequality.

Housing is obviously associated with many more dimensions of socio-economic inequality beyond the capital and income hypothesized about in this paper. Housing is a crucial reflection of residential segregation and the unequal access to a range of local services, ranging from education to all kinds of amenities and higher exposure to crime or other negative neighborhood effects (cf. Zavisca \& Gerber, 2016). The quality of, size of, and access to housing is another important source of housing inequalities (Dewilde \& Lancee, 2013). For the purposes of this paper, however, we zoom in on income-related inequalities to enrich the existing inequality literature on this topic by incorporating the housing dimension. 


\section{Empirical operationalization: a macro-micro mix}

To examine the empirical link between rent regulation and inequality through the lens of the three guiding hypotheses, we work on both the macro- and micro-levels of data analysis: the macro-analysis is based on a novel long-run 16-country panel that starts prior to World War I, when rent control was first implemented nationally by all countries affected by the war. This was also when the introduction of income taxation made the construction of income-based inequality measures possible in many countries. The micro-analysis takes advantage of international micro-survey data, which allows for examining the counterfactual effects of an introduction of rent controls on the inequality of post-housing disposable income and on the inequality of rental income flows for various international countries for a more recent time period.

\section{Data}

On the macro-level, we make use of the following dependent variables to approximate our three hypotheses: Wealth-to-income ratios from the World Inequality Database (WID) are the crucial measure for the "capital is back" claim and the wealth component contains housing as crucial asset in national wealth portfolios. As to rental income, the Gini coefficient, the top$10 \%$ income shares, and top- $1 \%$ income shares contain rental income flows as part of the capital income households receive. We use a combination of the standardized income inequality database (Solt, 2016) and WID, accessed through the merged dataset from Madsen et al. (2018). We prefer the Gini of disposable income for reasons of data coverage, but also show the Gini of market incomes. Rental expenditure, in turn, has figured historically as part of the expenditure items in national accounts (Knoll, Schularick, \& Steger, 2015). All these macro-variables are not perfect measures because they contain housing and rents as only one component, albeit an important, if not the most important one. On the macro-level and particularly for this long-run analysis, we cannot isolate the particular components, but can only use control variables and otherwise turn to the complementary micro-analysis.

The main explanatory macro-variable is rent control, which we approximate through coding historical rent laws into regulation indices for more than 100 countries since the inception of rent control (cf. Kholodilin, 2020a). The dataset reaches back to the first large-scale applications of rent controls in WWI. Initially, they were used in the form of rent freezes, when the rental prices were fixed at a constant level, e.g. at the price paid at a specific date or as a specific amount. Various institutions were responsible for fixing rents: courts, rent arbitration councils composed of representatives of tenants and landlords, or rental administrators appointed by the state. No rent increases were allowed without permissions of such entities. In some cases, the government even forced landlords to reduce ren. Since the early 1970, a softer form of rent control, such as rent stabilization, or second generation of rent control, emerged. This softer form implies that initial rent, at least theoretically, is set in a free negotiation between the landlord and the tenant at the market level. However, during the contract period, the rent increases are limited by some measure of the cost of living: e.g., consumer price index or mortgage interest rate. Since the 1910s, almost all countries had some form of rent control. 
By 2020, most countries abandoned it. Nevertheless, there are still countries applying either hard or soft form of rent controls. From this database, we use the rent price regulation index, which accounts for whether rent controls of nominal rents (or hard controls of the first regulation) or real rents (or soft controls of the second generation) are in place or not (Arnott, 1995). These index variables are standardized for a range from 0 to 1 (the higher the index the stricter rent control) and can account for the presence of national rent controls and, within limits, their intensity.

As macro-control variables, we draw on existing studies on the topic. We use standard controls, including GDP and population from the Macrohistory database (Jordà, Schularick, \& Taylor, 2017) as well as annual marriage rates and the old age dependency ratio as interpolated series from Mitchell and the World Bank for more recent periods (Mitchell, 2005). We use the national marginal tax rates of top-income earners as proxy for the extent of progressive taxation, taken from Scheve/Stasavage (2016) and extended with OECD tax data after 2010. For a robustness check, we use war casualties from the Correlates of War dataset (Sarkees \& Wayman, 2010). In Piketty's work, the difference between the real interest rate and economic growth is perhaps the central predictor for the fall and rise of income inequality (Piketty, 2014) and we follow Góes (2016) in using the difference of real 10-year government returns and real economic growth rates. In economic literature, more factors are tested in the long run, i.e., trade openness, left-government, union density, central bargaining, but all are insignificant (Scheve $\&$ Stasavage, 2009). It could be argued that the expansion of homeownership over the $20^{\text {th }}$ century reduced the importance of rent transfer from poor tenants to rich landlords. Therefore, we include the presence of condominium ownership in countries as a proxy for homeownership expansion. We attach a descriptive overview of all macro-data in the appendix.

On the micro-level, we draw on several waves of the Luxembourg Income Study (LIS) because it is among the few international micro-data sources to contain information on both rental expenditure of tenants and rental incomes of landlords. Moreover, it is the largest available income database of harmonized microdata covering 55 countries from the entire world between 1967 and 2018. We use the most recent waves for the subset of countries for which both rent regulation and the rental expense and rental expenditure variables are present in the survey. The micro-data allow a more fine-grained isolation of the rental expenditure and incomes than the national accounts. They also permit a decomposition of these variables by income decile. As there is no information on how respondents are directly affected by rent controls, we conduct a counterfactual test to see how strongly inequality of rent expenditures and incomes by income deciles is affected by introductions of rent controls of various intensity.

\section{Methodology}

On the macro-level, we estimate panel regression models, drawing on methodology used to assess the impact of governmental regulations on inequality. Our data have several specific features that need to be addressed properly. First, we deal with longitudinal data, which suggests the use of a panel data model. Second, most dependent variables persist over time. Therefore, we need dynamic models in order to capture the temporal autocorrelation and to 
investigate the relationships of interest. Third, there could be endogeneity issues. In particular, one can argue that it is not only tighter rent regulation that brings about less income inequality, but also that less income inequality brings about tighter rent regulation because, for instance, more equal societies vote for more rent-control friendly governments. Or inversely: higher inequality gives the top-10\% more power to obstruct rent control legislation. Typically, in such cases, the dynamic panel models are estimated using the GMM of Arellano and Bond (1991) because the lagged dependent variable can be correlated with the error term (Anderson \& Hsiao, 1981). However, given the long-term and multi-country nature of our data, it is extremely difficult to find appropriate instrumental variables. Moreover, in our dataset, the time dimension, $T$, is much larger than the number of countries, $N$, while the Arellano-Bond approach is more appropriate in the opposite situation (small $T$ and large $N$ ).

Therefore, we account for these three features by taking advantage of the panel vector autoregressive (VAR) model with country fixed effects:

$$
y_{i t}=A_{1} y_{i t-1}+A_{2} y_{i t-2}+\ldots+A_{p} y_{i t-p}+\eta_{i}+\epsilon_{i t}
$$

where $y_{i t}$ is a vector of all variables (including the dependent variable, rent control index, and control variables) for country $i$ in year $t ; \eta_{i}$ is a vector of the country fixed effects; $\epsilon_{i t}$ is the random disturbance; while $A_{1}, A_{2}, \ldots, A_{p}$ are the coefficient matrices to be estimated. The VAR model treats all variables as potentially endogenous and accounts for serial autocorrelation. We employ the panel unit root Im-Pesaran-Shin (2003) test in order to identify the non-stationary variables (for example, GDP per capita or old-age dependency ratio). ${ }^{2}$ Such variables are then transformed into growth rates or first differences. The optimal lag length is selected using the Schwarz information criterion. We use the first lag of the control variables and regulation indices in order to avoid possible endogeneity. If an endogeneity bias remains, it will rather underestimate the effect we are interested in.

\section{Results}

\section{Descriptive results}

The average trends of rent regulation across the last century are almost a mirror-image of income inequality trends (cf. Figure 1): Before WWI, inequality levels were at very high levels - measured by top income shares, the Gini of market and disposable income or the wealth-toincome ratio - while rent controls were nonexistent, with the exception of hardly enforced usury laws. With WWI, the modern tax state evolved toward progressive income taxation in parallel with the apparatus of strict rent price, eviction, and housing supply controls, with inequality levels starting to decrease. Rent controls were only partly removed in interwar Europe, partly moved into regular civil law (Voldman, 2013). With WWII, countries witnessed a re-introduction of strict controls, which were maintained into the postwar years (Führer,

\footnotetext{
2 The results of these tests are available upon request.
} 
1995). They were lifted earlier in Anglophone countries when compared with continental Europe, which transitioned into a regime of softer so-called second-generation rent controls constraining rent increases but not the initial rent levels since the early 1970s (Kholodilin, 2020a). Inequality started to rise again following the 1970s, when post-war rent controls were abolished or liberalized into second-generation controls. Both the rise in inequality and the deregulation of rental markets were more pronounced in Anglo-Saxon countries. For example, rent controls and the top- $10 \%$ income share have a bivariate correlation of about -0.3 . Prima facie then, both the housing-capital and the rental-income hypothesis find some bivariate evidence.

\section{Figure 1: Rent regulation and inequality}
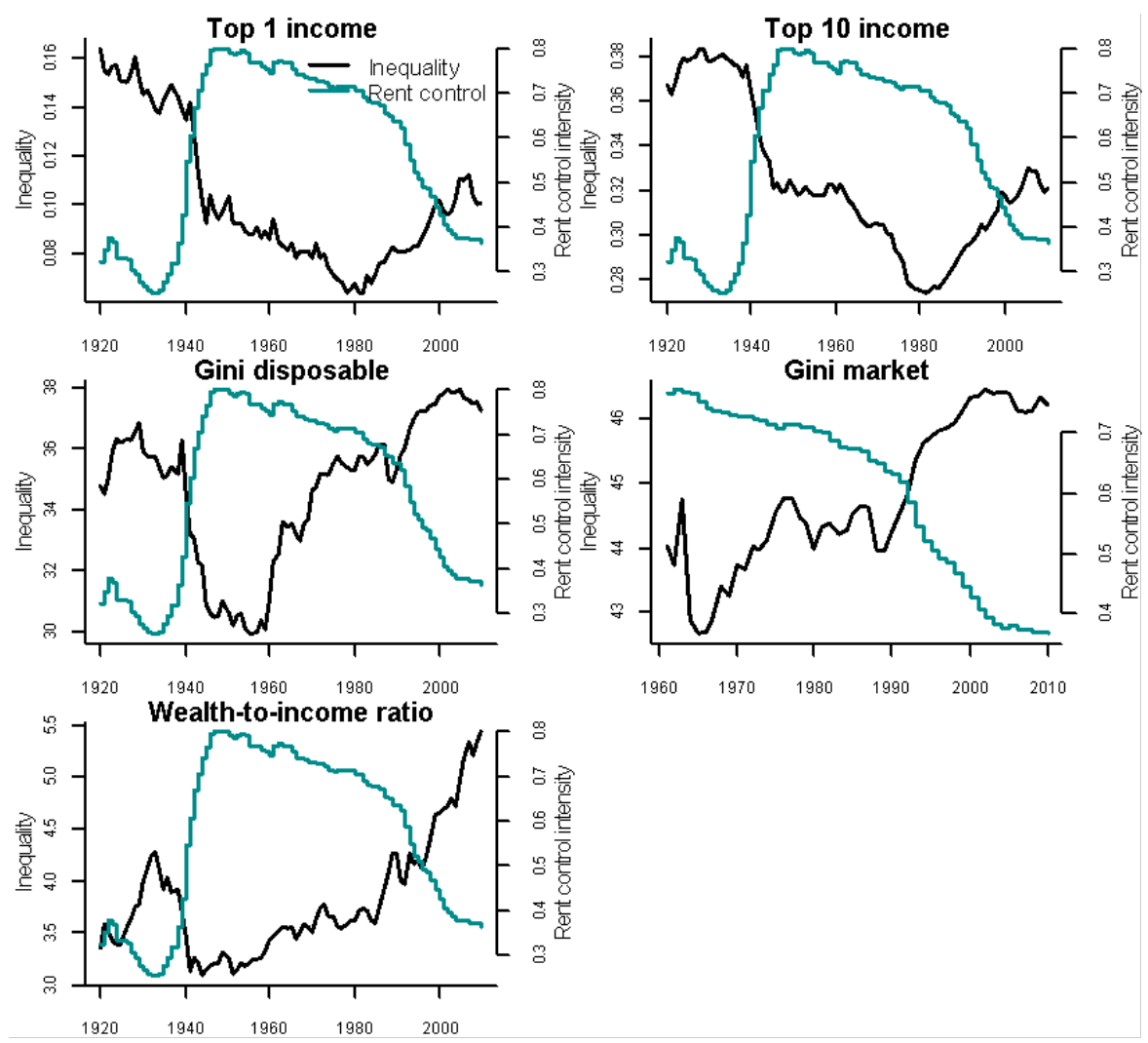

A similar association is found for households' housing expenditure and rent levels over time (cf. Figure 2). Historically, rent is a major component of household budgets and, with the decline of real food and textile prices, has even become the dominant expenditure in most countries. Housing cost (actual and imputed rents), sometimes including utilities, appear in most countries' national accounts' consumption statistics, even though they are not computed or surveyed in a standardized way and are rather harmonized within than across countries for long-time spans. For the shorter time span, the OECD offers specific time series of housing expenditure. Several individual country studies show, for the post-1970 period, that the 
increases are (entirely) due to increasing tenant expenditures (Albouy, Ehrlich, \& Liu, 2014; Dustmann et al., 2018) and that tenants have higher expenditure shares. With these given caveats, housing expenditure follows a common trend in most countries: it starts falling around 1900 , reaching a minimum in the post-WWI era, with rent controls only slowly fading out, then recovering only to fall again below mostly $15 \%$ budget share until the 1960 s. Ever since, with rent control being either completely removed (in Anglophone countries) or softened into a second-generation rent control in Europe, housing costs have started to rise persistently. Thus, on a bivariate level, the rental-expenditure hypothesis also has certain prima facie evidence.

Figure 2: Rent regulation, rent and housing expenditure over time

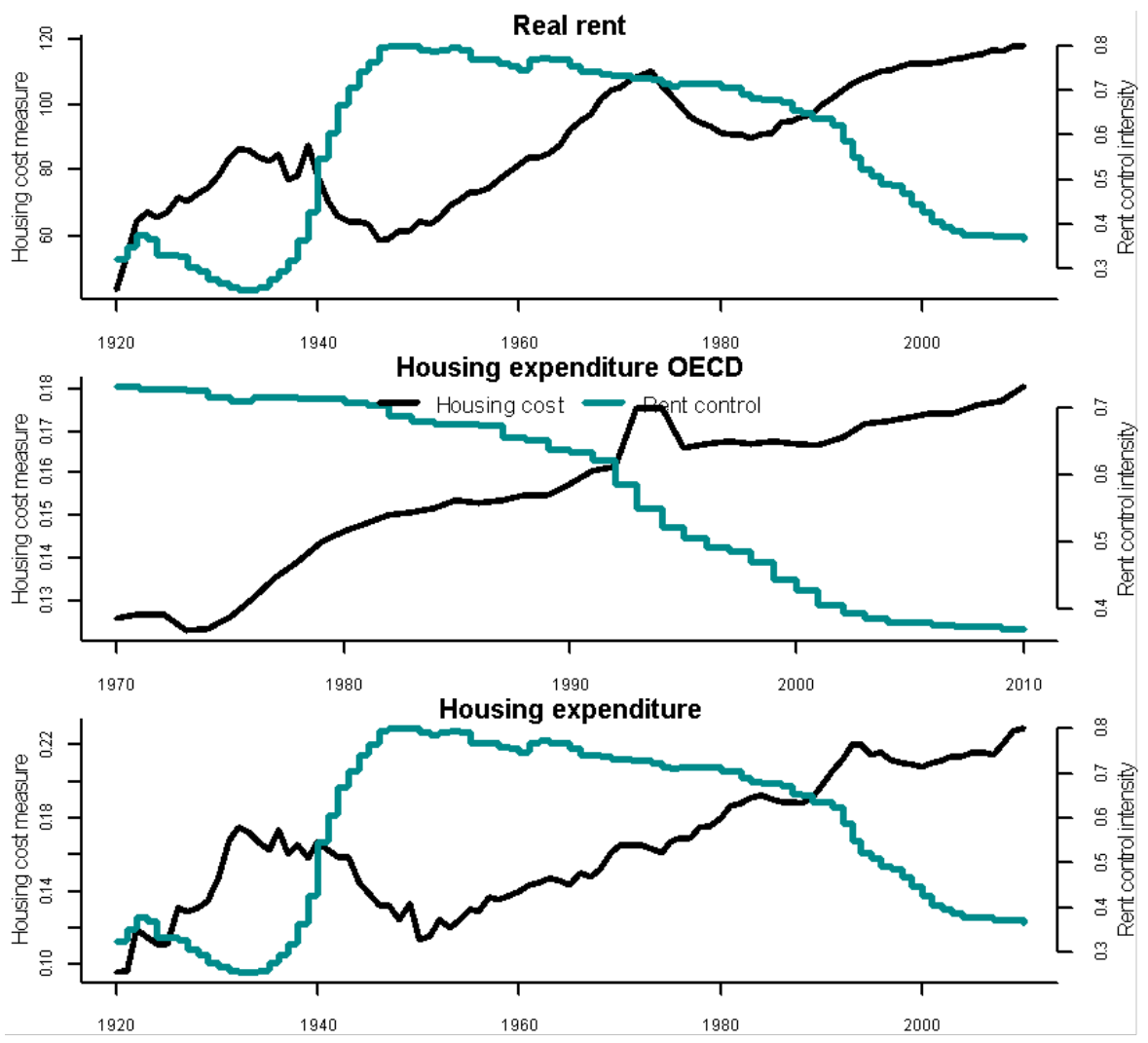

\section{Multivariate results}

To determine if the hypotheses also hold in a multivariate setting including standard explanations for inequality development, we estimate five different regressions in Table 1 with wealth-to-income ratios, the top- $10 \%$ income share, top- $1 \%$ income share, as well as the Gini coefficients for market and disposable income as dependent variables, respectively. 
Table 1: VAR model on capital-income, top-income shares, and Gini indices

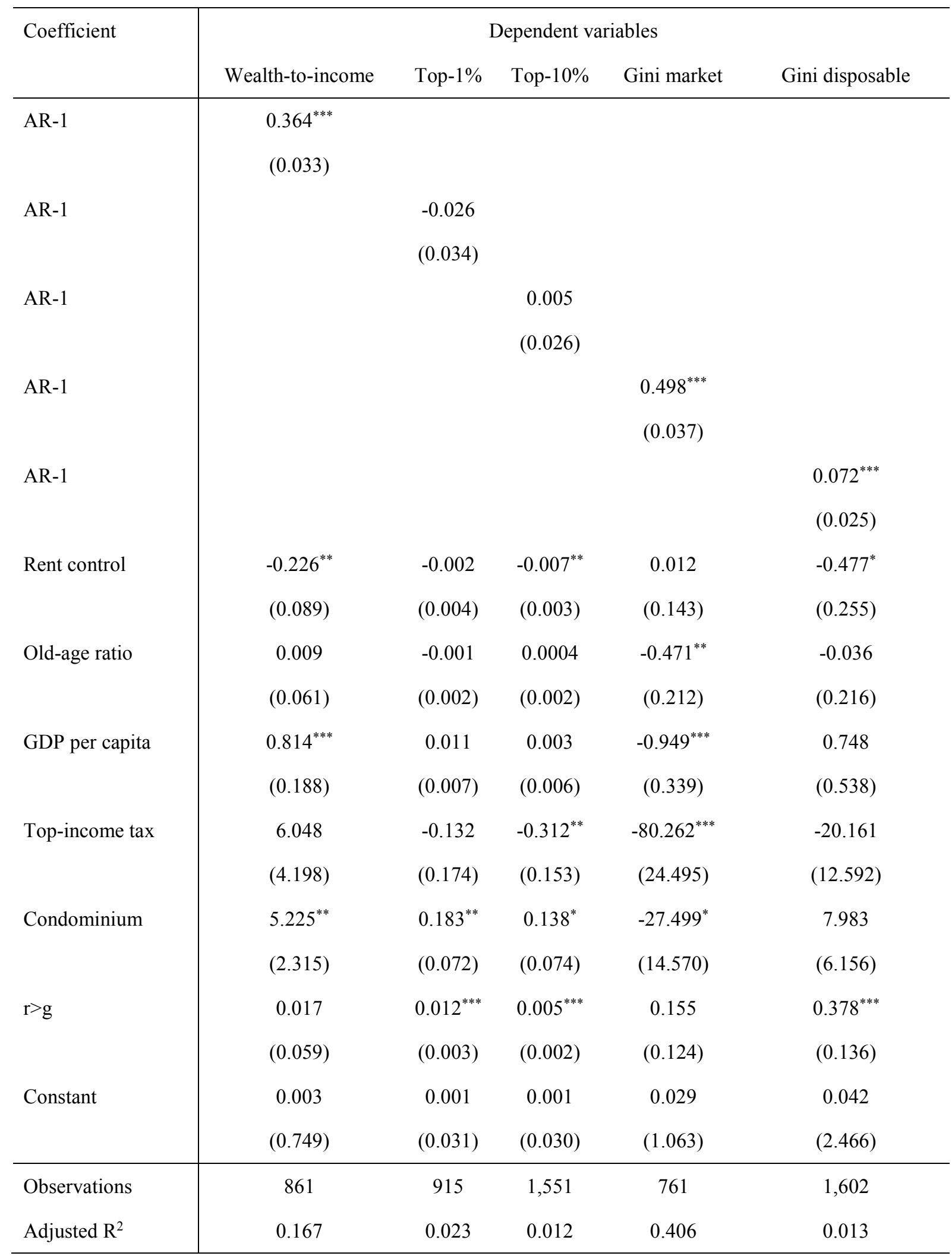

Note: $\quad * p<0.1 ; * * p<0.05 ; * * *<0.01$; independent variables are lagged first differences, the second lags of Gini-market model excluded. 
The estimates show a significant negative average effect of rent price controls on subsequent wealth-to-income ratios, top-10\% income shares, and the Gini coefficient of disposable incomes. It is negative also for the top- $1 \%$ incomes and the Gini of market incomes, but not significant, which could point to rental incomes being not important at the very top. These are also the two shorter series, which often exclude the pre-1950 years, which could point to historical effects being more important (see below). A one-point increase in the rent control index is followed by a decrease of the wealth-to-income ratio of 0.226 . The effect is stable when including typical control variables: the top-income-tax rates have the most persistent expected negative effect, while the old-age ratio and more widespread homeownership rather increase inequality. Disconfirming previous shorter-term analyses, our long-run analysis proves Piketty econometrically right: economic times when $r>g$ produce a statistically significant positive effect on inequality.

While this provides multivariate evidence in favor of the housing-capital and rental-income hypothesis, Table 2 speaks to the rental-expenditure hypothesis. Here the dependent variables are real rent price increases as well as housing expenditure shares in the OECD post-1970 short-run and in the very long run. Rent controls have a rent-price decreasing effect, which also has negative repercussions for housing budget shares (not significant in the long run). A onepoint increase in the rent control index is followed by a decrease of real rent growth by 0.047 and of housing expenditure by 0.005 units. This holds when controlling for demographics and wages (which have a rent-driving, but housing-expenditure lowering effect).

Table 2: Regression on rent increases and rental expenditure share

\begin{tabular}{l|ccc}
\hline Coefficient & \multicolumn{3}{|c}{ Dependent variables } \\
& Real rents & OECD housing expenditure & Long-run housing expenditure \\
\hline AR-1 & $0.367^{* * *}$ & & \\
& $(0.024)$ & $0.147^{* * *}$ & \\
AR-1 & & $(0.052)$ & $0.234^{* * *}$ \\
& & & $(0.032)$ \\
AR-1 & & & -0.004 \\
& & $-0.005^{*}$ & $(0.003)$ \\
Rent control & $-0.047^{* *}$ & $(0.003)$ & $0.004^{* *}$ \\
& $(0.019)$ & -0.0005 & $(0.002)$ \\
Old-age ratio & -0.004 & $(0.004)$ & -0.027 \\
& $(0.016)$ & $-0.093^{*}$ &
\end{tabular}




\begin{tabular}{l|ccc}
\hline \multirow{2}{*}{ Coefficient } & \multicolumn{3}{|c}{ Dependent variables } \\
& Real rents & OECD housing expenditure & Long-run housing expenditure \\
\hline \multirow{4}{*}{ Population } & $(0.126)$ & $(0.051)$ & $(0.017)$ \\
& -0.180 & 0.141 & $0.105^{* *}$ \\
& $(0.359)$ & $(0.108)$ & $(0.053)$ \\
Real wages & $0.151^{* * *}$ & $-0.028^{* *}$ & 0.004 \\
& $(0.031)$ & $(0.013)$ & $(0.005)$ \\
Constant & 0.005 & -0.0001 & 0.001 \\
& $(0.173)$ & $(0.018)$ & $(0.021)$ \\
\hline Observations & 1,604 & 412 & 947 \\
Adjusted $\mathrm{R}^{2}$ & 0.189 & 0.074 & 0.069 \\
\hline
\end{tabular}

Note: $\quad{ }^{*} p<0.1 ;{ }^{* *} p<0.05 ;{ }^{* *} p<0.01$; independent variables are lagged first differences, the second lags of the second model excluded

The above analysis already uses a number of different measures and finds mostly significantly negative effects of rent control on inequality through the three hypothesized channels. We conducted a number of robustness checks to further verify the results (reported in the Appendix). We first split our sample into two: first, 1949 or earlier ("historical") and, second, 1950 or later ("more recent"). While the overall rent control effects remain negative throughout, the more recent the period (and hence also number of observations), the less significance we have. This suggests that the rent control effect is more pronounced in the historical periods which also include the stricter controls and (post-)war periods. In the earlier period, housing wealth and rental income was also likely to be much more important than financial wealth or income its income. Before the post-WWII average introduction of condominium ownership, landlords were more likely to own entire apartment buildings with even more concentrated rental incomes. Therefore, we conduct a second robustness check in which we differentiate first-generation rent controls (rent freezes) from second-generation rent controls (rent stabilizations). Here, the significant negative effect is mostly attributable to the former type of controls, which coincide with the earlier time periods. Is rent control just reducible to the wars and their effects then? To explore this, we included war casualties as a war-time proxy in a third robustness check. The model still shows a significantly negative effect of rent control, distinct from wars. Overall, we take from this macro-analysis that rent controls, mostly of the stricter kind as applied in the more historical period, have had a significantly negative effect on inequality, in both the capital and income dimension.

\section{Micro-data simulation results}

On the micro-level, we start by examining whether the rental revenues and rental expenses are related to the household's income using the household-level data from the LIS database. We 
take the most recent available surveys. For this purpose, we compute the share of income obtained from renting out premises (rental income, coded as hi22, according to the LIS nomenclature of the variables) in the total income of the household (current income, or hitotal) as well as the share of the expenses on renting a dwelling (actual rent, or hc4l) in the total income of the household. The households are classified by quintiles, according to the per-capita income, which is computed as the current income divided by the number of household members (hitotal/nhhmem). The resulting figures calculated for 12 selected countries are reported in Table 3, which shows the average rental income share (upper panel) and average rental burden (lower panel) for each quintile. The numbers from 1 to 5 denote the income quintiles.

Table 3: Variation of rental revenues and rental burden across income quintiles

\begin{tabular}{lcccccc}
\hline \multirow{2}{*}{ Country } & Year & \multicolumn{5}{c}{ Rental income share, \% } \\
Austria & & 1 & 2 & 3 & 4 & 5 \\
\cline { 3 - 6 } Belgium & 2014 & 1.1 & 0.5 & 0.8 & 0.8 & 1.1 \\
France & 2016 & 0.9 & 0.9 & 1.4 & 2.1 & 2.5 \\
Germany & 2010 & 0.4 & 0.6 & 1 & 1.3 & 2.9 \\
Greece & 2016 & 0.9 & 1 & 1.4 & 2 & 3.2 \\
Israel & 2016 & 1.7 & 1.6 & 2 & 2.8 & 4.4 \\
Ireland & 2016 & 0.8 & 1.1 & 1.9 & 3 & 4.2 \\
Italy & 2016 & 0.2 & 0.3 & 0.8 & 0.9 & 1.8 \\
Netherlands & 2016 & 0.3 & 0.3 & 0.5 & 1.1 & 1.2 \\
Spain & 2013 & 0.3 & 0.5 & 0.3 & 0.6 & 0.8 \\
Switzerland & 2016 & 1.2 & 1 & 1.4 & 1.6 & 2.2 \\
UK & 2016 & 0.5 & 1.3 & 1.5 & 1.8 & 3.5 \\
\hline
\end{tabular}

Rental burden, \%

\begin{tabular}{|c|c|c|c|c|c|c|}
\hline & & 1 & 2 & 3 & 4 & 5 \\
\hline Austria & 2014 & 26.7 & 28.4 & 27.4 & 25 & 18.7 \\
\hline Belgium & 2016 & 30.3 & 27.9 & 26.7 & 24.6 & 20 \\
\hline France & 2010 & 5.7 & 11.2 & 13.2 & 14.3 & 14.6 \\
\hline Germany & 2016 & 30.5 & 27.9 & 26.5 & 24.3 & 19.9 \\
\hline Greece & 2016 & 10.1 & 3.3 & 2.7 & 2.2 & 1.5 \\
\hline Israel & 2016 & 33.7 & 28.2 & 26 & 23.5 & 21.4 \\
\hline Ireland & 2016 & 21.9 & 21.3 & 20.3 & 17.8 & 17.8 \\
\hline Italy & 2016 & 23.9 & 22.3 & 21.8 & 21.1 & 19.5 \\
\hline
\end{tabular}




\begin{tabular}{lcccccc}
\hline Country & Year & \multicolumn{5}{c}{ Rental income share, \% } \\
& & 1 & 2 & 3 & 4 & 5 \\
\cline { 3 - 7 } & & 27.5 & 25.7 & 24.6 & 25.6 & 24.7 \\
Netherlands & 2013 & 36.4 & 32.2 & 30.2 & 27.5 & 23.7 \\
Spain & 2016 & 19.3 & 17.4 & 16.8 & 15.6 & 12 \\
Switzerland & 2016 & 19.3 & 19.6 & 17.9 & 17.8 & 18.6 \\
UK & 2016 &
\end{tabular}

Source: Luxembourg Income Study and own calculations.

As expected, for most countries, the share of revenues from letting rental premises is increasing as a function of the income quintile: The higher the quintile, the higher the rental income share. While for the first quintile, the lowest-income $20 \%$ of the population, the share varies between 0.2 and $1.7 \%$, for the fifth quintile it ranges between 0.8 and $4.4 \%$. Recall that this seemingly low number relative to top incomes hides the high absolute numbers, the high concentration, and the high numbers relative to the bottom incomes. By contrast, the rental burden is decreasing as a function of the income quintile, confirming the "Schwabian law" of rental expenses. Households of the lowest per-capita income spend between 5.7 and $36.4 \%$ of their current income for rent, whereas households with the highest per-capita income expend just between 1.5 and $24.7 \%$ of their current income on rent.

Rent control is likely to affect the income distribution through two channels. On the one hand, by capping rents, it effectively reduces the rental revenue, with higher-income households suffering the largest income losses. On the other hand, it diminishes the expenditure on rental housing, with the lower-income households obtaining the biggest relative benefits. In order to assess the potential impact of rent control on the income distribution, we conduct a simple counterfactual analysis. We compute Gini indices and 80:20 ratios (the ratio of the average income of the highest quintile to that of the lowest of per-capita income distribution) for the actual data. Then, we set either rental income or rent expenditure to zero and calculate Gini indices for the modified data.

The counterfactual setting simulates the strictest possible rent controls, which are rarely was implemented in this form, with socialist housing regimes coming closest. Here, by 1989, rents had fallen to below 3\% of income and did not even cover operating expenses (Topfstedt, 1999). In other countries, rent freezes, especially during hyperinflation, can reduce the relative rental income and burden to virtually zero. For example, in Belgium between 1914 and 1920, consumer prices (rents excluded) rose more than $350 \%$, while rents were limited to no more than a $50 \%$ increase (Bettendorf \& Buyst, 1997, p. 655). Thus, the counterfactual values approximate an upper bound for rent control effects. The difference between these counterfactual and the real inequality measures, as presented in Table 4, offer the full range into which the effects of rent price controls can fall. 
Table 4: Potential impact of rent reduction on the income distribution

\begin{tabular}{|c|c|c|c|c|c|c|c|}
\hline \multirow[t]{2}{*}{ Country } & \multirow[t]{2}{*}{ Year } & \multicolumn{3}{|c|}{ Gini index, \% } & \multicolumn{3}{|c|}{ Decile ratio } \\
\hline & & $\begin{array}{c}\text { actual } \\
\text { distribution }\end{array}$ & $\begin{array}{l}\text { without rental } \\
\text { revenue }\end{array}$ & $\begin{array}{l}\text { without rental } \\
\text { burden }\end{array}$ & $\begin{array}{c}\text { actual } \\
\text { distribution }\end{array}$ & $\begin{array}{l}\text { without rental } \\
\text { revenue }\end{array}$ & $\begin{array}{l}\text { without rental } \\
\text { burden }\end{array}$ \\
\hline Austria & 2014 & 39.9 & 39.7 & 39.1 & 5.2 & 5.3 & 5.1 \\
\hline Belgium & 2016 & 32.0 & 32.0 & 30.8 & 4.2 & 4.2 & 4.0 \\
\hline France & 2010 & 33.3 & 32.9 & 33.0 & 4.3 & 4.2 & 4.2 \\
\hline Germany & 2016 & 36.3 & 35.6 & 34.5 & 5.2 & 5.1 & 4.6 \\
\hline Greece & 2016 & 34.8 & 34.5 & 34.8 & 5.1 & 5.1 & 5.1 \\
\hline Israel & 2016 & 42.1 & 41.8 & 41.7 & 7.8 & 7.7 & 7.6 \\
\hline Ireland & 2016 & 39.9 & 39.4 & 38.9 & 5.5 & 5.4 & 5.2 \\
\hline Italy & 2016 & 38.2 & 38.1 & 37.7 & 6.2 & 6.2 & 6.0 \\
\hline Netherlands & 2013 & 33.2 & 33.1 & 31.2 & 4.4 & 4.4 & 4.0 \\
\hline Spain & 2016 & 38.8 & 38.7 & 38.4 & 6.4 & 6.4 & 6.2 \\
\hline Switzerland & 2016 & 33.4 & 33.1 & 32.7 & 4.2 & 4.1 & 4.1 \\
\hline UK & 2016 & 38.2 & 38.2 & 37.4 & 5.2 & 5.2 & 5.0 \\
\hline
\end{tabular}

Source: Luxembourg Income Study and own calculations.

In all countries, except Belgium, the disappearance of the rental revenue leads to a reduction in the Gini index, while the 80:20 ratio falls only in five out of 12 cases. In six other countries, it remains unchanged, while in Austria it even increases. This finding possibly implies that the highest-income households are less dependent on revenues from the direct letting of housing. The decline of the Gini indices ranges between 0 and 0.7 percentage points. The effect of reduced rental burden is much larger: it varies between 0 and -2 percentage points. Figure 3 summarizes the range of counterfactual inequality reductions in percent changes of the Gini coefficient as a function of linearly increasing rent control strictness. The horizontal axis shows hypothetical rent price reductions, while the vertical axis depicts the relative effects on the Gini index. The results represent an average of 12 countries for 2010-2016. 
Figure 3: Counterfactual range of inequality reductions from soft to hard rent controls

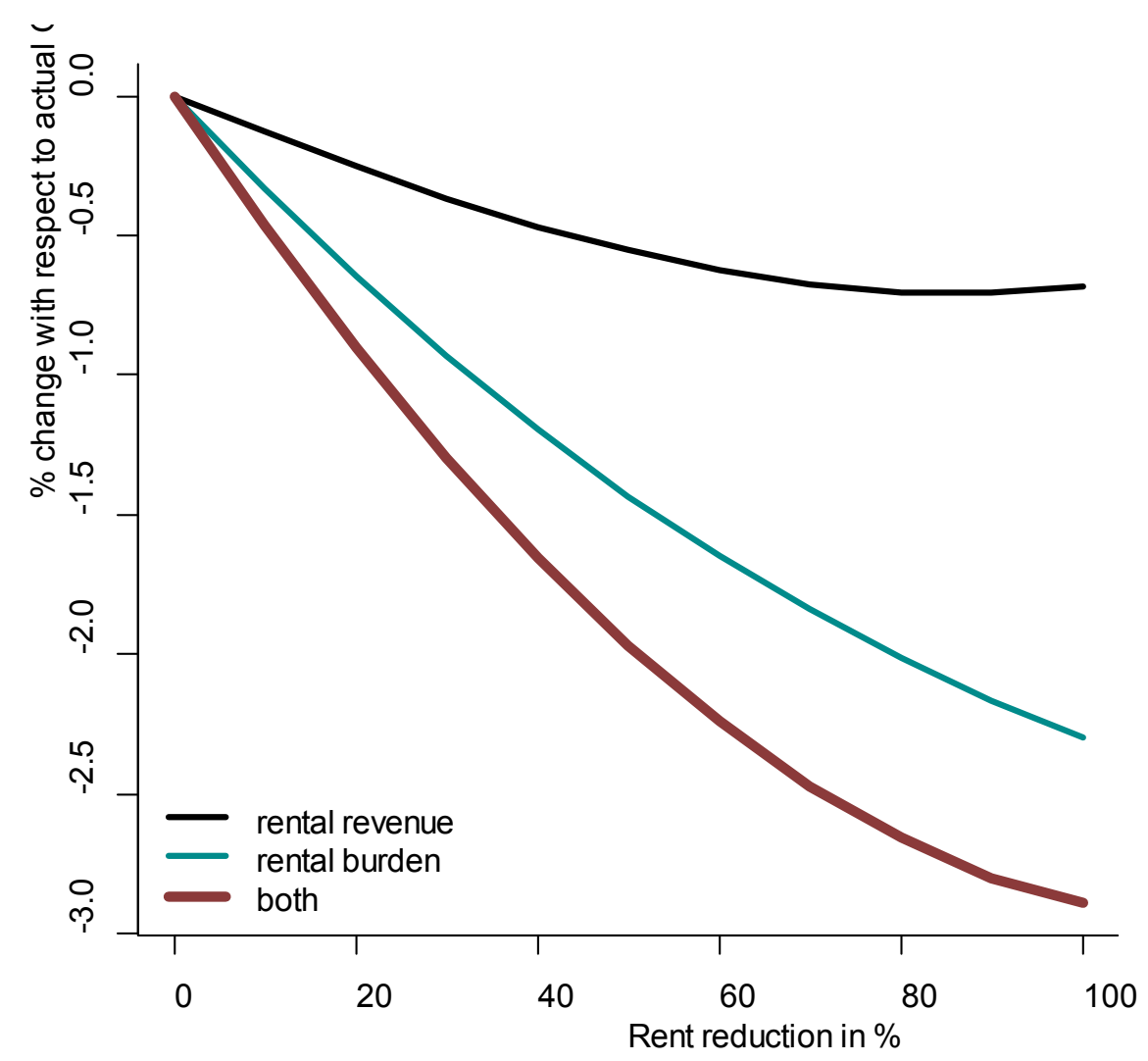

Note: The curves are based on the average changes for the following countries and years: Australia 2014, Belgium 2016" France 2010, Germany 2016, Greece 2016, Israel 2016, Ireland 2016, Italy 2016, Netherlands 2013, Spain 2016, Switzerland 2016, and the UK 2016.

Figure 3 shows that already moderate rent reductions related to rent control can lower the Gini coefficient by more than one percent. This effect is particularly driven by the reduction of the rent burden. The cumulative effect of both changes (red curve denoted as "both") is even larger: for a $30 \%$ rent reduction, the Gini decreases by more than $1 \%$. As a way of comparison, we calculated the difference between the Gini of market incomes and the Gini of disposable incomes in all countries since 1950. This can be interpreted as the total inequality decrease generated by the welfare state and amounts to a median of nearly $7 \%$. When compared to this global effect of welfare measures, a strict rent control effect is thus not negligible. The effects of rent reductions have, of course, been varying across time. For example, prior to WWII, before condominium ownership was introduced, landlords could own only entire buildings, which required far more financial means than acquiring single apartments. The vast majority of urban citizens were tenants. Thus, at that time, rent reductions might have had a much more sizeable effect than that estimated here for the 2010s. 


\section{Discussion and conclusion}

Although it is ignored by much inequality research, it is increasingly clear that housing is a crucial vector of economic inequalities. Housing divides might even supplant the classic laborcapital divide (Adkins, Cooper, \& Konings, 2019), re-structuring electoral politics as already witnessed in the surge of populism (Adler \& Ansell, 2019). The increasing unaffordability problems in superstar cities are reanimating a policy-idea that some consider to be just an exceptional war-time measure of days gone by: rent controls. Rather than a relic of the past, most European countries are actively using deregulated, softer, versions of the exceptional wartime measures, which once gave birth to the regulation of tenancy. Rent controls of the stricter kind have recently and controversially been introduced on the regional level in Berlin and Catalonia. The outbreak of the global COVID-19 pandemic is leading to the re-introduction of strict rent controls (Kholodilin 2020b). In many countries, as well as many subnational regions, rents were frozen for the duration of the sanitary emergency. In some, rent controls are likely to remain even after the crisis is over. Much criticized by economists for their supply distorting effects, rent controls are primarily motivated to protect tenants from price increases deemed too excessive when compared with income levels.

This paper investigates this secondary effect on housing inequality: the main take-away from the historical long-run perspective, which follows a century of national rent controls since their inception up to the current day, is that, in particular, the hard rent controls during and following the World Wars, part of the historic period, had inequality-decreasing effects that went beyond other often cited measures, like progressive income taxation or Piketty's own $r>g$ formula. The inequality decline runs through three channels: rent controls keep capital-wealth ratios lower, they lower landlords' incomes, and they increase tenants' post-housing disposable income. This is mainly because landlords are rich and tenants are poor, such that rent control acts as a channel for redistribution. This effect also holds despite the fact that, over the historic longrun, private tenancy has become less important. A counterfactual analysis on micro-data of landlords and tenants confirms that rent controls have the potential to lower the Gini coefficient and 80:20 ratios of the income distribution. Very soft rent control effects on inequality are of rather low magnitude and the macro effects of softer rent regulation and those outside of warcontexts are mostly not significant. This would imply that politicians interested in decreasing inequality through a cap on "rental capitalism" would rather have to use a "rent-bazooka" instead of the fine-grained comparative rent tables of soft control, but it could be part of a solidary package of income and capital taxation lowering levels of inequality.

One layer of complexity the paper does not touch upon is the various institutional forms of real estate ownership, i.e., rich individuals do not only hold residential real estate directly, but also indirectly through a variety of institutional ownership forms, shares in traded real estate companies, and Real Estate Investment Trusts, etc. One critical institution are the institutions of the second and third pillars of the pension systems. These privatized forms of pension provision are funded pensions and have increasingly found residential real estate to be a satisfying investment in time of decreasing yields on government bonds and other safe assets. 
In extreme cases, such as Switzerland with its more than $60 \%$ tenancy rate and one of the most privatized pension systems, tenants basically provide a private pension to the nation's retirees by paying large shares of their income as rent. Both private pensions and financial shares in real estate, are obviously skewed toward the upper-income parts of the population. To the extent that rent controls also affect the profitability of real estate holdings beyond individual households, our results rather underestimate the total effect rent controls can have on economic inequality.

Housing can affect inequalities in a multitude of ways and rent controls could have more effects of a longer-term nature than those investigated here (Turner \& Malpezzi, 2003). Rent controls are often associated with reduced residential mobility (Diamond, McQuade, \& Qian, 2019), which could create inequalities between existing tenants and the more mobile parts of the population. This could not only freeze existing segregation, but also prevent gentrification (Sims, 2011). Reduced mobility could also create mismatches in the labor market. Rent controls are also associated with underinvestment in both the housing stock and new supply as well as a flight into homeownership (Downs, 1988): to the extent that upper-income households are more likely to buy themselves out, rent controls could increase the quality divide between rental and owner-occupied units in the housing stock, while limiting the supply for new families and other mobile households, thus affecting intergenerational inequalities. Finally, rent regulations could be implemented in different ways, with richer households being rather able to evade them. All these are potential side effects that must be accounted for when interpreting our main finding that rent controls can potentially reduce inequality. 


\section{References}

Acemoglu, D., \& Robinson, J. A. (2015). The rise and decline of general laws of capitalism. Journal of Economic Perspectives, 29(1), 3-28.

Adkins, L., Cooper, M., \& Konings, M. (2019). Class in the 21st century: Asset inflation and the new logic of inequality. Environment and planning A: economy and space, $0308518 X 19873673$.

Adler, D., \& Ansell, B. (2019). Housing and Populism. West European Politics, 43(2), 344365.

Albouy, D., Ehrlich, G., \& Liu, Y. (2014). Housing demand and expenditures: How rising rent levels affect behavior and cost-of-living over space and time. Paper presented the CEP/LSE Labour Seminar, London.

Anderson, T. W., \& Hsiao, C. (1981). Estimation of dynamic models with error components. Journal of the American Statistical Association, 76(375), 598-606.

Arellano, M., \& Bond, S. (1991). Some tests of specification for panel data: Monte Carlo evidence and an application to employment equations. The Review of Economic Studies, $58(2), 277-297$.

Arnott, R. (1995). Time for Revisionism on Rent Control? Journal of Economic Perspectives, 9(1), 99-120.

Bartels, C., \& Schroeder, C. (2020). The role of rental income, real estate and rents for inequality in Germany. Paper presented at the Forum New Economy Working Papers.

Bettendorf, L., \& Buyst, E. (1997). Rent control and virtual prices: A case study for interwar Belgium. Journal of Economic History, 654-673.

Bonnet, O., Bono, P.-H., Chapelle, G., \& Wasmer, E. (2014). Does Housing Capital Contribute to Inequality? A Comment on Thomas Piketty's Capital in the 21st Century. Sciences Po Economics Discussion Paper, 7.

Bonneval, L., \& Robert, F. (2013). L'immeuble de rapport. L'immobilier entre gestion et spéculation. Rennes: Presses Univ. de Rennes.

Christelis, D., Georgarakos, D., \& Haliassos, M. (2013). Differences in portfolios across countries: Economic environment versus household characteristics. Review of Economics and Statistics, 95(1), 220-236.

Christophers, B. (2020). Rentier Capitalism: Who Owns the Economy, and Who Pays for It? : Verso.

Cobb, J. A., \& Lin, K.-H. (2017). Growing apart: The changing firm-size wage premium and its inequality consequences. Organization Science, 28(3), 429-446.

Daumard, A., \& Codaccioni, F. (1973). Les fortunes françaises au XIX. siècle: enquête sur la répartition et la composition des capitaux privés à Paris, Lyon, Lille, Bordeaux et toulouse d'après l'enregistrement des déclarations de succession. Paris: Mouton.

Dewilde, C., \& Lancee, B. (2013). Income Inequality and Access to Housing in Europe. European Sociological Review, 29(6), 1189-1200. doi:10.1093/esr/jct009

Diamond, R., McQuade, T., \& Qian, F. (2019). The effects of rent control expansion on tenants, landlords, and inequality: Evidence from San Francisco. American Economic Review, 109(9), 3365-3394.

Downs, A. (1988). Residential rent controls. Washington, DC: Urban Land Institute.

Dustmann, C., Fitzenberger, B., \& Zimmermann, M. (2018). Housing Expenditures and Income Inequality.

ECB. (2013). The Eurosystem Household Finance and Consumption Survey. Results from the First Wave. Statistics Paper Series, 2. 
Fetter, D. K. (2013). The Home Front: Rent Control and the Rapid Wartime Increase in Home Ownership. NBER Working Paper, 19604.

Führer, K. C. (1995). Managing Scarcity: The German Housing Shortage and the Controlled Economy 1914-1990. German History, 13(3), 326-355.

Fuller, G. W., Johnston, A., \& Regan, A. (2019). Housing prices and wealth inequality in Western Europe. West European Politics, 1-24. doi:10.1080/01402382.2018.1561054

Godechot, O. (2020). Financialization and the Increase in Inequality. In The Routledge International Handbook of Financialization: Routledge.

Góes, C. (2016). Testing Piketty's Hypothesis on the Drivers of Income Inequality: Evidence from panel VARs with heterogeneous dynamics: International Monetary Fund.

Gürer, E., \& Weichenrieder, A. (2020). Pro-rich inflation in Europe: Implications for the measurement of inequality. German Economic Review, 21(1), 107. doi:https://doi.org/10.1515/ger-2018-0146

Haffert, L. (2019). War mobilization or war destruction? The unequal rise of progressive taxation revisited. The Review of International Organizations, 14(1), 59-82.

Im, K. S., Pesaran, M. H., \& Shin, Y. (2003). Testing for unit roots in heterogeneous panels. Journal of Econometrics, 115(1), 53-74.

Jordà, Ò., Schularick, M., \& Taylor, A. M. (2017). Macrofinancial History and the New Business Cycle Facts. In M. Eichenbaum \& J. A. Parker (Eds.), NBER Macroeconomics Annual 2016, vol. 31. Chicago: Chicago University Press.

Kholodilin, K. A. (2020a). Long-Term, Multicountry Perspective on Rental Market Regulations. Housing Policy Debate, 30(6), 994-1015.

Kholodilin, K. A. (2020b). Housing policy during COVID-19 crisis: Challenges and solutions; https://rpubs.com/Konstantin_Xo/COVID19_housing_policies

Kholodilin, K. A., Kohl, S., Prozorova, Y., \& Licheron, J. (2018). Social Policy or Crowdingout? Tenant Protection in Comparative Long-run Perspective. DIW Discussion Papers.

Klein, M. C., \& Pettis, M. (2020). Trade wars are class wars: How rising inequality distorts the global economy and threatens international peace: Yale University Press.

Knoll, K., Schularick, M., \& Steger, T. (2015). No Price Like Home: Global House Prices, 1870-2012. Centre for Economic Policy Research Discussion Paper, 10166.

Kolb, K., Skopek, N., \& Blossfeld, H.-P. (2013). The Two Dimensions of Housing Inequality in Europe - Are High Home Ownership Rates an Indicator for Low Housing Values? Comparative Population Studies, 38(4), 1009-1040.

Le Galès, P., \& Pierson, P. (2019). "Superstar Cities" \& the Generation of Durable Inequality. Daedalus, 148(3), 46-72.doi:10.1162/daed_a_01750

Lehnhardt-Ritter, G. (1984). Das Kapitalanlageverhalten der deutschen Lebensversicherungsunternehmen im Wandel der Konjunktur: eine spektralanalystische und ökonometrische Untersuchung (Vol. 25). Karlsruhe: Verlag Versicherungswirtschaft.

Lux, M., Sunega, P., \& Katrňák, T. (2011). Classes and Castles: Impact of Social Stratification on Housing Inequality in Post-Socialist States. European Sociological Review, 29(2), 274-288. doi:10.1093/esr/jcr060

Madsen, J. B., Islam, M. R., \& Doucouliagos, H. (2018). Inequality, financial development and economic growth in the OECD, 1870-2011. European Economic Review, 101, 605624.

Milanovic, B. (2011). Worlds apart: Measuring international and global inequality: Princeton University Press.

Mitchell, B. R. (2005). International Historical Statistics: Europe, 1750-2000. Basingstoke: Palgrave Macmillan. 
Novokmet, F., Piketty, T., \& Zucman, G. (2018). From Soviets to oligarchs: inequality and property in Russia 1905-2016. The Journal of Economic Inequality, 16(2), 189-223.

Obinger, H., Petersen, K., \& Starke, P. (2018). Warfare and Welfare: Military Conflict and Welfare State Development in Western Countries: Oxford University Press.

Oust, A. (2018). The Removal of Rent Control and its Impact on Search and Mismatching Costs: Evidence from Oslo. International Journal of Housing Policy, 18(3), 433-453.

Pfeffer, F. T., \& Waitkus, N. (2020). The Wealth Inequality of Nations. LWS Working Paper Series, 33.

Piketty, T. (2014). Capital in the Twentieth-First Century. Cambridge, MA: Harvard University Press.

Piketty, T. (2020). Capital and Ideology. Cambridge: Harvard University Press.

Piketty, T., \& Zucman, G. (2013). Capital is Back. Wealth-Income Ratios in Rich Countries 1700-2010. Paris School of Economics.

Reckendrees, A. (2007). Konsummuster im Wandel. Haushaltsbudgets und privater Verbrauch in der Bundesrepublik 1952-98. Jahrbuch für Wirtschaftsgeschichte/Economic History Yearbook, 48(2), 29-62.

Rognlie, M. (2014). A note on Piketty and diminishing returns to capital. Unpublished paper, MIT.

Sarkees, M. R., \& Wayman, F. (2010). Resort to War: 1816 - 2007. Washington DC: CQ Press.

Scheidel, W. (2018). The great leveler: Violence and the history of inequality from the stone age to the twenty-first century (Vol. 74): Princeton University Press.

Scheve, K., \& Stasavage, D. (2009). Institutions, partisanship, and inequality in the long run. World Politics, 61(2), 215-253.

Scheve, K., \& Stasavage, D. (2016). Taxing the rich: A history of fiscal fairness in the United States and Europe: Princeton University Press.

Schwabe, E. (1868). Das Verhältnis von Miete und Einkommen in Berlin. Berlin und seine Entwicklung. Gemeindekalender und städtisches Jahrbuch, 2, 264-267.

Sims, D. P. (2011). Rent Control Rationing and Community Composition: Evidence from Massachusetts. In The B.E. Journal of Economic Analysis \& Policy (Vol. 11).

Solt, F. (2016). The standardized world income inequality database. Social science quarterly, 97(5), 1267-1281.

Stansbury, A., \& Summers, L. H. (2020). The Declining Worker Power Hypothesis: An Explanation for the Recent Evolution of the American Economy (0898-2937). Retrieved from

Topfstedt, T. (1999). Wohnen und Städtebau in der DDR. In M. Andritzky (Ed.), Geschichte des Wohnens. Band 5. 1945 bis heute. Aufbau. Neubau. Umbau (pp. 419-562). Stuttgart: Wüstenrot Stiftung.

Turner, B., \& Malpezzi, S. (2003). A review of empirical evidence on the costs and benefits of rent control. Swedish Economic Policy Review, 10(1), 11-60.

Visser, J. (2006). Union membership statistics in 24 countries. Monthly Lab. Rev., 129, 38.

Voldman, D. (2013). L'encadrement des loyers depuis 1900, une question européenne. [Rent Control Since 1900. A European Question]. Le Mouvement Social, 245, 137-147.

Wind, B., Dewilde, C., \& Doling, J. (2020). Secondary property ownership in Europe: Contributing to asset-based welfare strategies and the 'really big trade-off'. International Journal of Housing Policy, 20(1), 25-52.

Zavisca, J. R., \& Gerber, T. P. (2016). The Socioeconomic, Demographic, and Political Effects of Housing in Comparative Perspective. Annual Review of Sociology, 42(1), 347-367.

Ziegelmeyer, M. (2015). Other real estate property in selected euro area countries: Banque centrale du Luxembourg. 


\section{Appendix}

Table A1: Descriptive statistics of variables, macro-panel:

\begin{tabular}{lccccccc}
\hline Statistic & $\mathrm{N}$ & Mean & St. Dev. & Min & Pctl(25) & Pctl(75) & Max \\
& & & & & & & \\
\hline Wealth to income & 1,082 & 4.283 & 1.288 & 0.935 & 3.421 & 4.957 & 8.292 \\
Top 1\% income & 1,161 & 0.106 & 0.044 & 0.040 & 0.076 & 0.128 & 0.281 \\
Top 10\% income & 2,339 & 0.337 & 0.071 & 0.175 & 0.292 & 0.381 & 0.601 \\
Gini market income & 3,790 & 45.433 & 6.751 & 21.800 & 41.525 & 49.400 & 72.500 \\
Gini disposable income & 5,221 & 35.986 & 8.889 & 17.500 & 29.188 & 41.900 & 65.023 \\
Lag of real rents & 1,831 & 4.363 & 0.594 & 1.657 & 4.179 & 4.721 & 5.629 \\
Housing expenditure OECD & 891 & 0.172 & 0.029 & 0.100 & 0.152 & 0.190 & 0.304 \\
Housing expenditure long-run & 1,124 & 0.172 & 0.049 & 0.049 & 0.136 & 0.207 & 0.290 \\
Rent control index & 13,664 & 0.463 & 0.400 & 0 & 0 & 0.8 & 1 \\
Old age ratio & 7,729 & 7.580 & 4.404 & 1.131 & 3.866 & 10.596 & 26.565 \\
Marriage rate & 6,778 & 6.990 & 2.476 & 0.668 & 5.307 & 8.223 & 27.400 \\
Lag population & 9,546 & 9.051 & 1.611 & 4.963 & 8.060 & 10.075 & 14.132 \\
GDP per capita & 8,744 & 1.676 & 1.077 & -0.842 & 0.788 & 2.479 & 4.406 \\
Lag wage differences & 1,854 & 1.515 & 8.881 & -108.770 & -0.282 & 3.555 & 92.067 \\
Top income tax_rate & 2,082 & 0.447 & 0.229 & 0.000 & 0.280 & 0.600 & 0.975 \\
Interest minus growth rate & 1,937 & -2.341 & 19.333 & -495.397 & -7.393 & 4.933 & 82.225 \\
War deaths & 6,816 & 0.114 & 0.898 & 0.000 & 0.000 & 0.000 & 16.394 \\
& & & & & & & \\
\hline
\end{tabular}


Table A2: Alternative VAR-models for inequality: Hard vs. soft control

Wealth-to-income Top-1\% Top-10\% Gini-market Gini-disposable

\begin{tabular}{|c|c|c|c|c|c|}
\hline DW2I.11 & $\begin{array}{c}0.378^{* * *} \\
(0.033)\end{array}$ & & & & \\
\hline DTop_1_income.11 & & $\begin{array}{c}-0.026 \\
(0.034)\end{array}$ & & & \\
\hline DTop_10_income.11 & & & $\begin{array}{c}0.007 \\
(0.026)\end{array}$ & & \\
\hline Dgini_mkt.11 & & & & $\begin{array}{l}0.563^{* * *} \\
(0.031)\end{array}$ & \\
\hline Dgini_disp.11 & & & & & $\begin{array}{c}0.072^{* * *} \\
(0.025)\end{array}$ \\
\hline Rent control hard & $\begin{array}{c}-0.020 \\
(0.054)\end{array}$ & $\begin{array}{l}-0.004^{*} \\
(0.002)\end{array}$ & $\begin{array}{c}-0.004^{* *} \\
(0.002)\end{array}$ & $\begin{array}{c}-0.002 \\
(0.081)\end{array}$ & $\begin{array}{l}-0.175 \\
(0.148)\end{array}$ \\
\hline Rent control soft & $\begin{array}{c}\mathbf{0 . 0 1 2} \\
(0.086)\end{array}$ & $\begin{array}{c}-\mathbf{0 . 0 1 0} * * \\
(0.004)\end{array}$ & $\begin{array}{l}\mathbf{- 0 . 0 0 5} \\
(0.003)\end{array}$ & $\begin{array}{c}\mathbf{- 0 . 0 4 1} \\
(0.096)\end{array}$ & $\begin{array}{l}\mathbf{- 0 . 1 1 6} \\
(0.257)\end{array}$ \\
\hline DOld_age_ratio.11 & $\begin{array}{c}0.009 \\
(0.061)\end{array}$ & $\begin{array}{l}-0.001 \\
(0.002)\end{array}$ & $\begin{array}{l}0.0003 \\
(0.002)\end{array}$ & $\begin{array}{l}-0.174^{* *} \\
(0.080)\end{array}$ & $\begin{array}{l}-0.042 \\
(0.216)\end{array}$ \\
\hline DLGDP_PC.11 & $\begin{array}{c}0.870^{* * *} \\
(0.188)\end{array}$ & $\begin{array}{c}0.012^{*} \\
(0.007)\end{array}$ & $\begin{array}{c}0.004 \\
(0.007)\end{array}$ & $\begin{array}{l}-0.793^{* *} \\
(0.337)\end{array}$ & $\begin{array}{c}0.793 \\
(0.539)\end{array}$ \\
\hline Top_income_tax_rate.11 & $\begin{array}{c}6.061 \\
(4.219)\end{array}$ & $\begin{array}{l}-0.137 \\
(0.174)\end{array}$ & $\begin{array}{c}-0.312^{* *} \\
(0.153)\end{array}$ & $\begin{array}{c}-32.574^{* * * *} \\
(9.545)\end{array}$ & $\begin{array}{l}-19.966 \\
(12.604)\end{array}$ \\
\hline Condo.11 & $\begin{array}{l}5.355^{* *} \\
(2.329)\end{array}$ & $\begin{array}{l}0.188^{* * *} \\
(0.072)\end{array}$ & $\begin{array}{l}0.146^{* *} \\
(0.074)\end{array}$ & $\begin{array}{l}-3.315 \\
(6.137)\end{array}$ & $\begin{array}{c}8.478 \\
(6.164)\end{array}$ \\
\hline Capital_rtn.11 & $\begin{array}{c}0.032 \\
(0.059)\end{array}$ & $\begin{array}{c}0.012^{* * *} \\
(0.003)\end{array}$ & $\begin{array}{c}0.005^{* * *} \\
(0.002)\end{array}$ & $\begin{array}{c}0.152 \\
(0.123)\end{array}$ & $\begin{array}{c}0.390^{* * *} \\
(0.136)\end{array}$ \\
\hline const & $\begin{array}{c}0.003 \\
(0.753)\end{array}$ & $\begin{array}{c}0.001 \\
(0.031)\end{array}$ & $\begin{array}{c}0.001 \\
(0.030)\end{array}$ & $\begin{array}{c}0.010 \\
(1.071)\end{array}$ & $\begin{array}{c}0.042 \\
(2.468)\end{array}$ \\
\hline Observations & 861 & 915 & 1,551 & 762 & 1,602 \\
\hline Adjusted $\mathrm{R}^{2}$ & 0.160 & 0.029 & 0.012 & 0.396 & 0.011 \\
\hline
\end{tabular}


Table A3: Alternative VAR-models for housing cost: Hard vs. soft control

\begin{tabular}{|c|c|c|c|}
\hline & Real rents & $\begin{array}{l}\text { OECD housing } \\
\text { expenditure }\end{array}$ & $\begin{array}{l}\text { Long-run housing } \\
\text { expenditure }\end{array}$ \\
\hline$\overline{\text { DLreal_rent.11 }}$ & $\begin{array}{c}0.364^{* * *} \\
(0.029)\end{array}$ & & \\
\hline DHousing_expenditure_oecd.11 & & $\begin{array}{l}0.140^{* *} \\
(0.062)\end{array}$ & \\
\hline DHousing_expenditure.11 & & & $\begin{array}{c}0.207^{* * *} \\
(0.037)\end{array}$ \\
\hline Rent control hard & $\begin{array}{l}-0.005 \\
(0.014)\end{array}$ & $\begin{array}{c}-0.007^{* * *} \\
(0.002)\end{array}$ & $\begin{array}{c}-0.002 \\
(0.002)\end{array}$ \\
\hline Rent control soft & $\begin{array}{c}-\mathbf{0 . 0 0 4} \\
(0.029)\end{array}$ & $\begin{array}{c}\mathbf{0 . 0 1 0} \\
(0.003)\end{array}$ & $\begin{array}{c}\mathbf{0 . 0 0 4} \\
(0.003)\end{array}$ \\
\hline Old_age_ratio.11 & $\begin{array}{c}0.062 \\
(0.086)\end{array}$ & $\begin{array}{l}-0.025 \\
(0.026)\end{array}$ & $\begin{array}{c}0.020^{*} \\
(0.010)\end{array}$ \\
\hline Marriage_rate_interp.11 & $\begin{array}{c}0.205 \\
(0.211)\end{array}$ & $\begin{array}{l}-0.050 \\
(0.037)\end{array}$ & $\begin{array}{c}0.011 \\
(0.025)\end{array}$ \\
\hline DLpop.11 & $\begin{array}{c}0.005 \\
(0.448)\end{array}$ & $\begin{array}{l}0.213^{* *} \\
(0.089)\end{array}$ & $\begin{array}{c}0.081 \\
(0.060)\end{array}$ \\
\hline DLRwages.11 & $\begin{array}{c}0.137^{* * *} \\
(0.038)\end{array}$ & $\begin{array}{c}-0.034^{* *} \\
(0.015)\end{array}$ & $\begin{array}{c}0.003 \\
(0.005)\end{array}$ \\
\hline DWar_deaths.11 & $\begin{array}{c}0.002 \\
(0.006)\end{array}$ & $\begin{array}{l}0.250^{* *} \\
(0.125)\end{array}$ & $\begin{array}{l}-0.002 \\
(0.001)\end{array}$ \\
\hline const & $\begin{array}{c}0.006 \\
(0.228)\end{array}$ & $\begin{array}{l}0.0003 \\
(0.021)\end{array}$ & $\begin{array}{c}0.001 \\
(0.025)\end{array}$ \\
\hline$\overline{\text { Observations }}$ & 1,154 & 253 & 699 \\
\hline Adjusted $\mathrm{R}^{2}$ & 0.171 & 0.130 & 0.048 \\
\hline
\end{tabular}


Table A4: VAR-Models for inequality with War-time variables

Wealth-to-income Top-1\% Top-10\% Gini-market Gini-disposable

\begin{tabular}{|c|c|c|c|c|c|}
\hline DW2I.11 & $\begin{array}{l}0.410^{* * *} \\
(0.041)\end{array}$ & & & & \\
\hline DTop_1_income.11 & & $\begin{array}{c}-0.108^{* * *} \\
(0.041)\end{array}$ & & & \\
\hline DTop_10_income.11 & & & $\begin{array}{c}-0.077^{* *} \\
(0.031)\end{array}$ & & \\
\hline Dgini_mkt.11 & & & & $\begin{array}{l}0.559^{* * *} \\
(0.039)\end{array}$ & \\
\hline Dgini_disp.11 & & & & & $\begin{array}{c}0.049 \\
(0.031)\end{array}$ \\
\hline DRent_laws.11 & $\begin{array}{l}-0.130 \\
(0.104)\end{array}$ & $\begin{array}{l}-0.008^{*} \\
(0.005)\end{array}$ & $\begin{array}{c}-0.013^{* * *} \\
(0.004)\end{array}$ & $\begin{array}{l}-0.010 \\
(0.158)\end{array}$ & $\begin{array}{l}-0.351 \\
(0.265)\end{array}$ \\
\hline DOld_age_ratio.11 & $\begin{array}{l}-0.032 \\
(0.081)\end{array}$ & $\begin{array}{l}-0.002 \\
(0.002)\end{array}$ & $\begin{array}{l}-0.0003 \\
(0.002)\end{array}$ & $\begin{array}{l}-0.012 \\
(0.126)\end{array}$ & $\begin{array}{l}-0.115 \\
(0.258)\end{array}$ \\
\hline DLRwages.11 & $\begin{array}{c}0.017 \\
(0.165)\end{array}$ & $\begin{array}{l}-0.002 \\
(0.007)\end{array}$ & $\begin{array}{c}0.002 \\
(0.005)\end{array}$ & $\begin{array}{c}-1.390^{* *} \\
(0.671)\end{array}$ & $\begin{array}{l}-0.123 \\
(0.368)\end{array}$ \\
\hline Top_income_tax_rate.11 & $\begin{array}{l}9.902^{* *} \\
(5.000)\end{array}$ & $\begin{array}{l}-0.360^{*} \\
(0.201)\end{array}$ & $\begin{array}{c}-0.472^{* * *} \\
(0.171)\end{array}$ & $\begin{array}{l}-16.672 \\
(11.899)\end{array}$ & $\begin{array}{l}-19.942 \\
(12.294)\end{array}$ \\
\hline Condo.11 & $\begin{array}{c}4.126 \\
(2.809)\end{array}$ & $\begin{array}{l}0.225^{* *} \\
(0.087)\end{array}$ & $\begin{array}{l}0.185^{* *} \\
(0.090)\end{array}$ & $\begin{array}{c}8.148 \\
(9.130)\end{array}$ & $\begin{array}{c}0.912 \\
(6.540)\end{array}$ \\
\hline Capital_rtn.11 & $\begin{array}{l}-0.036 \\
(0.075)\end{array}$ & $\begin{array}{l}0.009^{* * *} \\
(0.004)\end{array}$ & $\begin{array}{l}0.004^{* * *} \\
(0.002)\end{array}$ & $\begin{array}{c}0.204 \\
(0.151)\end{array}$ & $\begin{array}{c}0.433^{* * *} \\
(0.132)\end{array}$ \\
\hline War casualties & $\begin{array}{c}\mathbf{- 0 . 0 3 2} \\
(0.023)\end{array}$ & $\begin{array}{c}\mathbf{- 0 . 0 0 1} \\
(0.001)\end{array}$ & $\begin{array}{c}-\mathbf{- 0 . 0 0 1} \\
(0.001)\end{array}$ & $\begin{array}{l}\mathbf{- 1 . 9 8 1} \\
(6.679)\end{array}$ & $\begin{array}{c}-\mathbf{0 . 1 9 6} \\
(0.069)\end{array}$ \\
\hline const & $\begin{array}{c}-0.054 \\
(0.907)\end{array}$ & $\begin{array}{c}0.003 \\
(0.039)\end{array}$ & $\begin{array}{c}0.001 \\
(0.036)\end{array}$ & $\begin{array}{c}0.123 \\
(1.388)\end{array}$ & $\begin{array}{c}0.071 \\
(2.594)\end{array}$ \\
\hline Observations & 549 & 604 & 1,070 & 483 & 1,056 \\
\hline Adjusted $\mathrm{R}^{2}$ & 0.188 & 0.036 & 0.024 & 0.382 & 0.016 \\
\hline
\end{tabular}


Table A5: VAR-Models for housing cost with War-time variables

\begin{tabular}{|c|c|c|c|}
\hline & $\begin{array}{l}\text { Real } \\
\text { rents }\end{array}$ & $\begin{array}{l}\text { OECD housing } \\
\text { expenditure }\end{array}$ & $\begin{array}{l}\text { Long-run housing } \\
\text { expenditure }\end{array}$ \\
\hline DLreal_rent.11 & $\begin{array}{c}0.355^{* * *} \\
(0.029)\end{array}$ & & \\
\hline DHousing_expenditure_oecd.11 & & $\begin{array}{c}0.118^{*} \\
(0.062)\end{array}$ & \\
\hline DHousing_expenditure.11 & & & $\begin{array}{l}0.205^{* * *} \\
(0.037)\end{array}$ \\
\hline DRent_laws.11 & $\begin{array}{c}-0.060^{* *} \\
(0.025)\end{array}$ & $\begin{array}{c}-0.013^{* * *} \\
(0.004)\end{array}$ & $\begin{array}{l}-0.004 \\
(0.003)\end{array}$ \\
\hline DOld_age_ratio.11 & $\begin{array}{c}-0.011 \\
(0.023)\end{array}$ & $\begin{array}{c}0.009^{* * *} \\
(0.003)\end{array}$ & $\begin{array}{c}0.003 \\
(0.002)\end{array}$ \\
\hline Marriage_rate_interp.11 & $\begin{array}{c}0.169 \\
(0.171)\end{array}$ & $\begin{array}{l}-0.050 \\
(0.031)\end{array}$ & $\begin{array}{l}-0.013 \\
(0.021)\end{array}$ \\
\hline DLpop.11 & $\begin{array}{l}-0.185 \\
(0.457)\end{array}$ & $\begin{array}{l}0.371^{* * *} \\
(0.101)\end{array}$ & $\begin{array}{c}0.069 \\
(0.060)\end{array}$ \\
\hline DLRwages.11 & $\begin{array}{c}0.147^{* * *} \\
(0.037)\end{array}$ & $\begin{array}{l}-0.026^{*} \\
(0.015)\end{array}$ & $\begin{array}{c}0.004 \\
(0.005)\end{array}$ \\
\hline War casualties & $\begin{array}{c}\mathbf{0 . 0 0 2} \\
(0.006)\end{array}$ & $\begin{array}{l}\mathbf{0 . 2 6 3} \\
(0.124)\end{array}$ & $\begin{array}{c}\mathbf{- 0 . 0 0 2} \\
(0.001)\end{array}$ \\
\hline const & $\begin{array}{c}0.006 \\
(0.227)\end{array}$ & $\begin{array}{l}0.0005 \\
(0.021)\end{array}$ & $\begin{array}{c}0.001 \\
(0.025)\end{array}$ \\
\hline Observations & $\begin{array}{l}1,154 \\
0176\end{array}$ & 253 & 699 \\
\hline Adjusted $\mathrm{R}^{2}$ & 0.176 & 0.132 & 0.046 \\
\hline
\end{tabular}

Note: $\quad * p<0.1 ; * * p<0.05 ; * * * p<0.01$ 